\title{
ICSU Re-examines its Purpose
}

ICSU, the International Council of Scientific Unions, is the ultimate umbrella of international non-governmental organizations in science. Whether they know it or not, a large proportion of the worlds scientists are linked to it through their involvement in ICSU member societies, associations and programs such as the International Geological Correlation Programme, the Association of Exploration Geochemists or the International Palaeontological Association. ICSU is in the process of reviewing and assessing its role in the international world of science in order to identify needs and challenges that it should address in the coming years.

Several questions are now being asked in ICSU circles. What is it that we should be doing? Are we only an umbrella group or should we be doing more for the cause of science worldwide? Should ICSU, for example, be an international science council, the non-governmental voice for science? How can ICSU achieve its goals? There are also the perennial questions of how to promote more effective communications both among members of the ICSU family and to its "environment," and how to mobilize the necessary financial resources and professional staff.

ICSU has already become to some extent more "pro-active" in the last few years, for example through its study of nuclear winter and in its promotion of the global change concept. Yet despite the mandate for a larger role in the ICSU Constitution, there are those who feel that the Council has already found its niche on the global scene, and that it should continue to concentrate on "pure science," functioning quietly at the highest levels of the international scientific world.

The recent ICSU Futures Conference at Schloss Ringberg near Munich was designed to explore these issues and to open up the debate to distinguished scientists with little of no direct ICSU experience. As reported in the last issue of Episodes, the recommendations of the working groups that met there come down strongly in favour of an increased role for the Council, especially as regards communication with the world outside, broadening its scope to include the medical sciences, the social sciences, and engineering, and participation of developing countries.

The Ringberg conference is simply the first, an "overture," in a series of discussions: re-examination of fundamentals will take time. In the process of soul searching, ICSU should take a more strategic approach, keeping in mind the external environment on which it depends and which it serves, and with a clear identification of its "clients" and constituency. In strategic planning one must address in sequence:

- Issues - of political of scientific concern, bearing in mind that those initially identified by scientists (for example acid rain) may become public issues.

- Need - what is the specific need to be gddressed?

- How - the making of a project proposal.

- Project priorities - scientific quality, calibre of leaders, feasibility, relevance, urgency, likelihood of funding, potential for institutional support.

- Funding - the search should stress current public issues.
- Implementation - completion - project not necessarily finished when results or interpretations are published.

- Follow-through - the responsibility to inform the public and decision makers of problems that exist and their solution.

In order to carry out any recommendations that may be made, various assumptions will have to be made, and it will be necessary to establish priorities according to various policy issues. It would be a mistake, for example, for ICSU to attempt to take over the role Unesco now plays in international science; the huge organization that would be required would soon develop the kind of bureaucracy that no one would want. On the other hand an annual budget of say $\$ 10,000,000$ and a staff of 50 dedicated scientists and their support personnel could work wonders. This should not be beyond the realms of possibility.

In any case, if ICSU is to change its focus from science for the sake of science - as one Ringberg participant put it, on "scientific poetry" - to science for the sake of society, there is much to be done. Obviously the task will not be an easy one, but to quote another contributor at Ringberg, "if ICSU turns its back on society, then society may turns its back on ICSU."

W.W. Hutchison President, IUGS

\section{IN COMING ISSUES}

THE SOCIETY OF ECONOMIC GEOLOGISTS

ODP AT AGE ONE

MINING IN ANTARCTICA

EXOTIC TERRANES OF SOUTH AMERICA

ENVIRONMENTAL SEISMOLOGY

MID-TERM REPORT ON THE LITHOSPHERE PROGRAM

SEDIMENTS OF THE NORTH ARABIAN GULF

IUGS CONSIDERS GLOBAL CHANGE

COMMISSION ON STRATIGRAPHY GUIDELINES 